\title{
Nikolai Gumilyov and Théophile Gautier ${ }^{1}$
}

И не одно сокровище, быть может, Минуя внуков, к правнукам уйдет, И снова скальд чужую песню сложит И как свою ее произнесет. ${ }^{2}$

-Osip Mandelstam, 1914

$\mathcal{R}$ evival of poets condemned by the poetics of the preceding decades was a prominent feature of the Russian Silver Age. That was the time when Vladimir Solovyov rehabilitated Fet, that bête noire of the radical utilitarians (Lev Tolstoi and Chaikovsky may have loved Fet's poetry, but the entire dynasty of nineteenth-century vlastiteli $d u m,{ }^{3}$ from Belinsky to Mikhailovsky, never tired of mocking and reviling it). Sergei Andreevsky rescued Baratynsky from Belinsky's curse. Bryusov brought Karolina Pavlova back from near-total obscurity, and Aleksandr Blok, in his remarkable essay "Sud'ba Apollona Grigor'eva" (The fate of Apollon Grigoriev), saw the poet and critic Grigoriev as the "only bridge that unites us with Pushkin and Griboedov—a flimsy [bridge] suspended over the terrifying precipice of intellectual stagnation (bezvremen'e)."

The one prominent exception among the senior Symbolists was $\mathrm{Zi}$ naida Gippius, whose abiding sympathy for Belinsky, Chernyshevsky, and Pisarev was motivated by her radical politics; her misguided contempt for Chekhov; her animosity (for intimate personal reasons) toward Diaghilev

1 Originally published as "Nikolai Gumilev and Théophile Gautier" in Cultural Mythologies of Russian Modernism: From the Golden Age to the Silver Age, ed. Boris Gasparov, Robert P. Hughes, and Irina Paperno (Berkeley: University of California Press, 1992), 327-36.

2 "And not just one treasure, perhaps, / Passing grandsons by, will go on to greatgrandsons, / And anew a skald will arrange another's song / And deliver it as though it were his own."-Ed.

3 So-called intellectual authorities.-Ed.

4 Aleksandr Blok, Sobranie sochinenii v vos'mi tomakh, vol. 5 (Moscow and Leningrad, 1962), 513-14. 
and the developments in the visual arts launched by Mir iskusstva (World of Art); and her aversion to the early productions of the Moscow Art Theater, which she saw as the theatrical equivalent of Diaghilev's aesthetics. ${ }^{5}$ But many Postsymbolist poets sided with Diaghilev and Blok on the subject of nineteenth-century radical-utilitarian vlastiteli dum.

Examples extend all the way from Gumilyov's 1910 essay "Zhizn' stikha," where he lauded Russian Symbolism for "defending cultural values subjected to rough treatment [by writers] from Pisarev to Gorky" and for "instilling in the savages of the Russian press if not respect for great names and ideas, then at least a fear of them"-_to Vladislav Khodasevich's 1938 defense of Vladimir Nabokov's novel Dar (The gift). Khodasevich foresaw that the novel's jaundiced view of the Russian literary critics of the 1860s, shown in parodistic and grotesque terms in chapter 3 of Dar, "will undoubtedly cause the author many troubles. All the disciples and admirers of the progressive mental police that oversaw Russian literature since the forties of the last century are sure to become infuriated. Their hegemony is not yet quite over and they are sure now to soar over the author of Dar in a classical swarm of newspaper gadflies and mosquitoes."7 Like his senior Symbolist contemporaries, Nikolai Gumilyov also undertook the rehabilitation of a poet rejected and reviled by the votaries of nineteenth-century utilitarianism, only in this case the poet whose champion Gumilyov became was not a Russian one, but the French Romantic Théophile Gautier (1811-72).

Romantic poetry appeared in France later than it did in Germany, England, or Russia. Poems with clear Romantic features were published by Lamartine and Hugo in the 1820s, but it was the turbulent opening night of Hugo's Hernani on 25 February 1830 that gained for the poets of the Romantic movement their general recognition. The nineteen-year-old Théophile Gautier, who had not yet published anything of note, was a prominent presence at that riotous opening night, with his long hair and wearing a vest of scarlet red velvet, the vest that became his trademark in the popular imagination, comparable to Vincent van Gogh's amputated ear or Mayakovsky's blouse of yellow necktie silk. As Gautier was to note

5 Zinaida Gippius, Zhivye litsa, vol. 2 (Prague, 1925; repr. Munich, 1971), 158-59.

6 N. Gumilev, Sobranie sochinenii v chetyrekh tomakh (Washington: V. Kamkin, 196268), 4:169-70.

7 Vladislav Khodasevich, “Sovremennye zapiski, kn. 66-aia," Vozrozhdenie (Paris), 24 June 1938, 4-5. 
at the end of his life: "That red vest! I wore it only once and yet I'm dressed in it all my life. Our poetry, our books, our essays, our travelogues will be forgotten, but our red vests will be remembered."

Trying to pinpoint the nature of Gautier's Romanticism, Maurice Bouvier-Ajam found that the one common denominator which united Gautier with other French Romantics, Parnassians and even the early Symbolists (e.g., Baudelaire) was that they all rejected the literature and the poetics of the long reign of Louis XIV (1643-1715). ${ }^{9}$ Recoil from neoclassical poetics of the seventeenth and eighteenth centuries was, of course, typical of the Romantic movements in various countries, but in Russia, for example, the poets of Pushkin's time could jettison Sumarokov and Kheraskov while continuing to admire Fonvizin, Knyazhnin, and Derzhavin. In France, things were more sweeping: there was the tremendous authority of Boileau, revered from the end of the seventeenth to the first third of the nineteenth century, to be overthrown. And there had been a swarm of splendid poets, from Villon and Charles d'Orléans in the early fifteenth century to Ronsard and Saint-Amant, to free, as Gumilyov put it, "from the curse laid on them by Boileau" and to restore to their earlier luster. This is precisely what Gautier, following the example of Charles Sainte-Beuve, did in his Les grotesques (1844).

The parallels between the revolt against the radical-utilitarian domination in which Acmeist poets followed the Symbolist example and the clearly similar revolution in aesthetics whereby the young Gautier and other French Romantics overthrew the neoclassical and rationalistic dogma codified by Boileau were sufficient reason for Gumilyov to regard Gautier as a kindred spirit. But there were other affinities that united these two poets across the eight decades that separated their respective formulations of their literary theories. Unlike his one-time classmate and close friend, Gérard de Nerval, Gautier had no interest in Romantic mysticism. He expressed this in his oft-cited motto, "I am one of those for whom the exterior world exists," a statement borne out by his poetry, if not by certain of his novels.

8 Cited by René Jasinski in Europe (Paris), no. 601 (May 1979), 4. This special issue devoted to Gautier contains, inter alios, René Jasinski, “Situation de Théophile Gautier”; Maurice Bouvier-Ajam, "Le romantisme de Théophile Gautier”; Jacques Gaucheron, "Ombres et lueur de l'art pour l'art"; Serge Fauchereau, "Où Pound et Eliot recontrent Goumilev, Mandelstam et Akhmatova”; and Russell S. King, "Émaux et camées: sculptures et objets-paysages."

9 Maurice Bouvier-Ajam in Europe, no. 601, 25ff. 
Gautier also shunned all political involvement. In the 1833 preface to his narrative poem Albertus (the first two stanzas of which were brilliantly rendered into Russian by Gumilyov in his essay on Gautier) the French poet stated that "[the author of this book] has no political coloring; he is neither red, nor white, nor even tricolored; he is none of these and he takes notice of revolutions only when their bullets break his windows." ${ }^{10}$ After the compulsory politicization of Russian criticism in the second half of the nineteenth century, this must have seemed like a fresh breeze in the second decade of the twentieth. Like Gumilyov, Gautier traveled to remote areas in search of romantically picturesque visual impressions. $\mathrm{He}$, too, saw the task of any artist, including a poet, in wrestling with the inert matter of this world until it yields a new kind of beauty (compare his programmatic poem "L’art," which concludes Émaux et camées, with Paul Verlaine's vastly different "Art poétique"). But even apart from ideological or aesthetic considerations, it would be hard to think of another earlier figure who embodied the Acmeist ideal, as expressed in Gumilyov's theoretical writings, as closely as did Gautier.

During his lifetime and at the time of his death in 1872, the position of Gautier in the French literary pantheon seemed secure. His plays and ballets with his scenarios were performed, his novels and travelogues were read and admired, Hector Berlioz and other composers set his poetry to music, and his most comprehensive collection of verse, Émaux et camées, went through six editions between 1852 and 1872. In 1857, Charles Baudelaire dedicated his Fleurs du mal to Gautier, calling him "the impeccable poet," "the perfect magician of French literature" and "my very dear and very venerated teacher and friend." In the memorial volume Le tombeau de Théophile Gautier, brought out after the poet's death, we find contributions by several generations of French writers, ranging from Victor Hugo's homage, "À Théophile Gautier," which is virtually a history of the French Romantic movement and of Gautier's role in it, to Stéphane Mallarmé's much-anthologized "Toast funèbre."

But within a decade or two, Gautier's reputation suffered a precipitous decline in his native country. Turn-of-the-century French critics, such as Émile Faguet, Ferdinand Brunetière, and Gustave Lanson found Gautier

10 Cited by Claudine Gothot-Mersch in Théophile Gautier, Émaux et camées (Paris: Gallimard, 1981), 9, and by Jacques Gaucheron in Europe, no. 601, 80. 
minor, obsolete, "a poet who entered literature with absolutely nothing to say" (Faguet's formulation, which will be more than familiar to any student of Russian nineteenth- or twentieth-century literature). In the first decade of the twentieth century, Gautier was remembered in France chiefly as the author of Capitaine Fracasse, a novel considered suitable to be read by schoolchildren. As a poet, he was given credit for his ability "to copy, without thought or emotion, fragments of the surrounding world that he happened to experience"11 — a description that repeats with hallucinatory precision the judgments published in the 1880s by Skabichevsky and Mikhailovsky about the writings of the man they called "Gospodin Chekhov."

In the 1930s, with a renewed interest in the Romantic age, Théophile Gautier's oeuvre began making the comeback that gradually restored it to the position it deserves. In 1979 the French literary monthly Europe, founded by Romain Rolland, which had earlier devoted special issues to such luminaries as Mozart, Mikhail Sholokhov, Voltaire, Shakespeare, Maksim Gorky and Nazim Hikmet, among others, brought out an excellent collection of Gautier studies, which included Serge Fauchereau's essay on Gautier's impact on the American Imagists and Russian Acmeists. For, decades before the French reclaimed Gautier, he was taken up almost simultaneously by the Anglo-American Imagists and in Russia by Mikhail Kuzmin, the presiding spirit of Acmeism, and Nikolai Gumilyov, its most vocal theoretician.

As Clarence Brown put it in his book on Osip Mandelstam, "the fact is that some four or five years earlier [than 1917, i.e., ca. 1912], and apparently independently of each other, Gumilyov and his associates on the one hand, and [Ezra] Pound and [T. E.] Hulme and their associates, on the other, had invented or reinvented more or less the same thing. The points of similarity between the goals of the Anglo-American Imagists and those of the Russian Acmeists are so striking that they tease the mind almost intolerably. They had rediscovered the viability in their own age of the kind of poetry advocated by Théophile Gautier-whom both Pound and Gumilyov, incidentally, explicitly hailed as their preceptor."12 Gautier's impact on the poetry of Pound and, especially, T. S. Eliot has been

11 Dismissive turn-of-the-century views on Gautier cited by Jasinski, Europe, no. 601, 12-13.

12 Clarence Brown, Mandelstam (Cambridge: Cambridge University Press, 1973), 137. 
exhaustively demonstrated by René Taupin. ${ }^{13}$ Edmund Wilson ${ }^{14}$ and Serge Fauchereau ${ }^{15}$ have drawn on Taupin's findings.

The Russian rediscovery of Gautier seems to predate the AngloAmerican one. Sergei Diaghilev, Aleksandr Benois and other members of the World of Art group were deeply involved with Gautier, as can be seen from the programs of the first Diaghilev ballet seasons in Paris. In 1909, the company made its debut with Le pavillon d'Armide, a ballet whose scenario Benois based on a conte by Gautier. In 1910, Diaghilev repatriated the ballet with Gautier's most famous scenario, Giselle, to France after its many years of exile in Russia. Next year came Le spectre de la rose, with a plot credited to Jean-Louis Vaudoyer, yet actually based on a poem by Gautier that had been earlier set to music by Hector Berlioz. ${ }^{16}$ (Berlioz's Les nuits d'été, op. 7, no. 2, "Le spectre de la rose," is a setting of a poem from Gautier's La comédie de la mort.)

It was that same year, 1911, that Nikolai Gumilyov published his essay on Gautier, accompanied by his translations into Russian of four Gautier poems. They appeared in the prestigious art journal Apollon (no. 9). In the essay, Gumilyov praised not only Gautier's formal perfection, but also his "boundless Rabelaisian merriment" and his "wildly joyous thinking." 17 "The secret of Gautier is not that he is perfect, but that he is powerful-like Rabelais, like Nimrod, like a big and brave beast of the forest," Gumilyov wrote. Among the poems by Gautier which Gumilyov translated to accompany this essay were the programmatic "Lart," with its assertion that "Lart robuste / Seul a l'éternité"; and "L'hippopotame" (from Gautier's Poésies diverses) which asserts the poet's total independence from all current opinion, and which was later developed and expanded by T. S. Eliot into his anticlerical "The Hippopotamus."18

13 René Taupin, L'influence du symbolisme français sur la poésie américaine (de 1910 à 1920) (Paris: H. Champion, 1929), in particular 134, 135, and 155-58 on Pound and 236-40 on Eliot.

14 Edmund Wilson, Axel's Castle: A Study in the Imaginative Literature of 1870-1930 (New York: C. Scribner's Sons, 1931), 98-99.

15 Serge Fauchereau in Europe, no. 601.

16 John Percival, The World of Diaghilev (New York: E. P. Dutton, 1971), 136-37; Boris Kochno, Diaghilev and the Ballets Russes (New York: Harper \& Row, 1970), 24, 48, and 60 .

17 Gumilev, Sobranie sochinenii, 4:386-94.

18 Ibid., 1:189-95; Taupin, L'influence du symbolisme, 238-40. 
The apex of Gumilyov's involvement with Gautier came with the publication in 1914 of his translation of the complete text of Gautier's most comprehensive collection of verse, Émaux et camées. His later essay on translating verse postulated a number of basic requirements that must be met: reproduction of the meter and the rhyme scheme of the original, finding the appropriate vocabulary in the target language, keeping the same number of lines, etc. ${ }^{19}$ He said nothing about preserving the imagery of the original, and this is the area where Gumilyov's translations make some very drastic departures from Gautier's originals.

The volume as a whole is a remarkable labor of love. Some of the poems, such as "Premier sourire du printemps," "Rondalla," "Bûchers et tombeaux," "Le souper des armures" and "Dernier vœu" have been rendered into Russian with astounding fidelity, preserving both the form and the tone of the originals. But some of Gumilyov's versions are flawed. The blemishes come in the following varieties: (1) incomprehension of French (there are very few of these, but they are spectacular); (2) introduction of new ideas or imagery not found in Gautier; (3) passages that emerge as comical in Russian but were dead serious in French; and (4) misinterpreting references to music or opera (Gautier worked for decades as a music critic; Gumilyov had no expertise in this area, though he must have consulted someone because some of the musical terminology was translated correctly).

Among the failures to understand the text, three may be cited. In the introductory sonnet that opens the collection, Gautier alludes to Goethe's West-östlicher Divan, where the song of the hoopoe is mentioned. Gautier cited from Goethe the Persian name of this bird, Hudhud (apparently related etymologically to the Russian $u d o d$ ). Gumilyov mistook this Persian bird for a woman's proper name and translated the line as "Pel o Gudut, zhivushchei siro" (Sang of Gudut and her lonely life). ${ }^{20}$ In the poem "Impéria," about an Italian sixteenth-century courtesan, Gautier imagined as one of her pastimes wild outings on horseback with a group of bohemian friends:

Courses folles dans les bohèmes

Sur le dos des coursiers sans frein.

19 Gumilev, Sobranie sochinenii, 4:190-96.

20 Cf. Gautier, Émaux, 25, and Teofil' Got'e, Emali i kamei, trans. N. Gumilev (St. Petersburg: M. V. Popov, 1914), 5. 
Gumilyov must have read bohème as bohémien, "Gypsy," because he translated these lines most poetically but incorrectly as:

Езда на лошади цыганской,

На дикой лошади равнин

(Riding a Gypsy horse,

The savage horse of the plains). ${ }^{21}$

Finally, the most amazing misreading is found in the poem "La mansarde," which ends with a portrait of an old woman with a gaunt profile who is scolding her kitten:

Et l'on ne voit contre la vitre

Qu'une vieille au maigre profil,

Devant Minet, qu'elle chapitre.

Gumilyov somehow mistook the usual nickname for French kittens, Minet, for an Orthodox calendar of saints, and replaced Gautier's rather cozy picture with a very grim one indeed:
И за окошком все страшнее
Старуха тощая молчит,
Погружена в Четьи-Минеи
(And beyond the window, ever more terrifying,
The gaunt old woman remains silent,
Engrossed in her Calendar of Saints). ${ }^{22}$

Imagery not present in Gautier is strewn about liberally by Gumilyov, a procedure that Vladimir Nabokov once condemned as otsebiatina (roughly "adding one's own stuff"). Nabokov even coined a new English verb from this well-known Russian term, "to otsebiatinate." In the poem "Ce que disent les hirondelles," the Hajjis (i.e., Moslems who have made

21 Gautier, Émaux, 33, and Got'e, Emali, 23.

22 Gautier, Émaux, 134, and Got'e, Emali, 218. 
a pilgrimage to Mecca) count their amber prayer beads in Gautier, but Gumilyov has them play a game of checkers instead:

Хаджи играют в шашки мирно,

С ногами сидя на софе.

In the second stanza of "La rose-thé," a butterfly alights on the rosebush. Gumilyov turns it into a nightingale, which then bursts into song, something a butterfly couldn't do. What's more, Gumilyov smuggles a line from Tyutchev into this stanza: the rose listens to the nightingale's love song, "Vnimaia povesti liubovnoi" (Tyutchev had "Vnimaet povesti liubimoi"; there are also instances of Pushkin lines slipped into Gautier in other poems).

Moments of unintended comedy occur when Gumilyov deprives of dignity the historical personages whom Gautier treated with reverence. In the prefatory sonnet, Goethe withdraws from the turmoil of the Napoleonic wars to seclude himself and write his West-östlicher Divan:

Comme Goethe sur son divan

À Weimer s'isolait des choses.

Gumilyov changes that divan into an actual piece of furniture, takhta, to which the aged German poet rushes (and on which he possibly even leaps) quite indecorously:

Как Гете на свою тахту

В Веймаре убегал от прозы.

And in the poem about the old veterans of Napoleon's campaigns, "Vieux de la vieille," where Gautier had the ghost of the emperor review the ghosts of his soldiers who perished at Austerlitz, Gumilyov undermines the image by dressing Napoleon in incongruous civilian garb:

Где Император на параде

Проходит в шляпе и пальто

(Where the emperor at the parade

Passes by in hat and coat). 
Gumilyov got into difficulties about music and musical terminology in two specific instances. One was his rendition of the poem "Contralto," Gautier's homage to the voice of his common-law wife, the singer Ernesta Grisi. ${ }^{23}$ Gumilyov's one real failure in the collection is the sequence of four poems, called jointly "Variations sur le Carnaval de Venise." Almost all the poems in Émaux et camées are written in French octosyllabic verse with cross rhymes that alternate feminine and masculine endings, which Gumilyov quite appropriately conveyed with the familiar Russian iambic tetrameter. But the lines of the "Carnaval de Venise" poems, especially the second one, "Sur les lagunes," also suggest the popular barrel organ melody which serves as the theme for the cycle, the song known in most Western languages as "The Carnival of Venice," except in German, where it is called "Mein Hut der hat drei Ecken." The tune is hummable to a French octosyllabic line with a feminine ending, but there is no way to fit into it lines of Russian iambic tetrameter, which is what Gumilyov offers. To fit this tune to a Russian meter would require an amphibrachic trimeter with a truncated first foot:

Nor did Gumilyov manage to preserve the imagery of the second poem of the cycle, particularly of the two passages that Oscar Wilde cited in The Picture of Dorian Gray as the quintessential verbal reflections of the visual impression produced by Venice. In the first of these citations, the all-important musical image, "Sur une gamme chromatique," is replaced by Gumilyov with a literary one, "V volnen'i legkogo razmera," while in the second fragment cited by Wilde,

Devant une façade rose,

Sur le marbre d'un escalier,

23 See the detailed analysis of this particular poem and its handling by Gumilyov in S. Karlinsky, "Contralto: Rossini, Gautier and Gumilev," in Language, Literature, Linguistics: In Honor of Francis J. Whitfield on His Seventieth Birthday, March 25, 1986, ed. Michael S. Flier and Simon Karlinsky (Berkeley, 1987). [Reprinted in the present volume.] 
the equally central image of marble was omitted by Gumilyov:

\section{Пред розовеющим фасадом \\ Я прохожу ступеней ряд. ${ }^{24}$}

But all these shortcomings should not obscure the fact that Gumilyov's Emali i kamei is an astounding achievement. In the arts, if not in biology, one is free to select one's parents or ancestors. Whether it was a case of Goethean elective affinity or a Bakhtinian literary dialogue, Gumilyov constructed a monument to his love for and closeness to a French poet who died a decade and a half before Gumilyov was born and who was disdained in France throughout Gumilyov's life. This monument deserves to be read and studied more than it has been until now.

Among SK's first published reviews were those of the path-breaking edition in four volumes of the writings of Nikolai Gumilyov prepared in the 1960s by Gleb Struve and Boris Filippov. (Translations were not included.) His acute formulations of the stature of Gumilyov (who was executed by the new Bolshevik regime in August 1921) deserve to be cited:

Although no work of his was reprinted in the Soviet Union since 1923, and although his name has been unmentionable in the Soviet press until very recently, Gumilyov has steadily continued to exercise an influence on the Russian poetry of the present century, both Soviet and émigré. Even those who are not attracted to the military and exotic themes of some of his poetry (Gumilyov's occasional showy heroics are similar to Kipling's bouts of manliness that irked Max Beerbohm and to the compulsive manly stance of Hemingway that Gertrude Stein saw fit to ridicule) have to recognize Gumilyov's work not only as the major phenomenon of Russian poetry that it is but also as an important fact of modern Russian sensibility. ${ }^{25}$

24 Gautier, Émaux, 38, and Got'e, Emali, 36.

25 Simon Karlinsky, review of Sobranie sochinenii v chetyrekh tomakh, vol. 1, by Nikolai Gumilev, ed. G. P. Struve and B. A. Filippov (Washington: Kamkin, 1962), Books Abroad 37 (Autumn 1963): 471-72. 
SK refined his opinions upon reading Gumilyov's more mature poetry:

As Professor Struve points out in his lucid survey of Gumilyov's literary evolution, and as is amply illustrated by the poetry gathered in this second volume, there are several tenacious clichés about the nature of Gumilyov's work which in the light of his later and more mature poems no longer make sense. Gumilyov's own tragic and violent death generated a legend, nourished by the earlier poetry of adventure and exploration, Gumilyov as a purveyor of dashing heroic, and somewhat juvenile, poetry that was supposedly redeemed only by the poet's deliberate and precise craftsmanship.

With all his lyric poetry gathered and perusable in its entirety, we see that the Gumilyov of the popular cliché represents only one aspect of this poet. Gumilyov the maître of the Acmeist school, with his championing of simple and direct poetic communication and his admiration for Théophile Gautier, also turns out to be a particular aspect or mask of this protean poet-although in this case the Acmeist image has been fostered by literary historians rather than by the popular legend. The startling new image that emerges after one reads the second volume of his collected works is that of Gumilyov the visionary neo-Symbolist mystic who tends to couch his visions in authentically surrealistic imagery. We have been aware of this side of Gumilyov because of one of his most famous and frequently anthologized poems, "The Lost Streetcar"; we can see now that this poem was not exceptional in his work, but that it represents a definite and major strain in the poetry Gumilyov wrote in the last five years of his life. Nor is this the only unexpected side of Gumilyov revealed by the second volume: there is an equally surprising orthodox religiosity; a gentle humor we do not usually associate with this poet; fine and subtle treatments of contemporary themes, as in the delightful brief novella in verse "When I Was in Love ..." (pp. 193-95). We owe a debt of gratitude to the editors of this volume for making us realize that Gumilyov was not only a brilliant poet, but a deep and many-sided one as well. ${ }^{26}$

26 Simon Karlinsky, review of Sobranie sochinenii, vol. 2, by Nikolai Gumilev, ed. G. P. Struve and B. A. Filippov (Washington: Kamkin, 1964), Books Abroad 40 (Winter 1964): 106-7. SK went on to publish reviews of vols. 3 and 4 of this 4 -volume edition of Gumilyov's collected writings: Books Abroad 41 (Autumn 1967): 480; and Books Abroad 43 (Spring 1969): 278-79. 